\title{
Deoxyribonucleic acid damage and its detection
}

\author{
Özüm Atasoy' ${ }^{1}\left[\right.$, Oytun Erbaş² ${ }^{[}$ \\ ${ }^{1}$ Department of Radiation Oncology, Dr. Lütfi Kırdar Kartal Training and Research Hospital, Istanbul, Turkey \\ ${ }^{2}$ Department of Physiology, Demiroğlu Bilim University, Faculty of Medicine, Istanbul, Turkey
}

\begin{abstract}
Deoxyribonucleic acid (DNA) is exposed to countless exogenous and endogenous agents that can cause damage. It is estimated that a single cell can undergo up to a million changes in DNA in a single day as a result of these agents. Inability to repair these DNA damages causes mutation, in turn, mutagenesis leads to cancer development. Therefore, knowledge of the factors that cause DNA damage and their mechanisms as well as detection of these damages is important in the health and future of organisms.

Keywords: Cell death, deoxyribonucleic acid, mutagenicity, X-rays.
\end{abstract}

Since DNA is the source of genetic information in every living cell, its integrity and stability are vital to life. However, DNA is not inert; it is exposed to attacks from its environment and if unrepaired, any damage will result in mutation and possibly disease. ${ }^{[1]}$ The integrity of human genomic DNA is constantly threatened by many factors. These factors can be roughly divided as endogenous and exogenous factors. Endogenous factors are spontaneous errors that occur in DNA or as a result of exposure to reactive oxygen radicals produced as a by-product of cellular metabolism, lipid peroxidation products, endogenous alkylating agents, estrogen and cholesterol metabolites, reactive carbonyl products. ${ }^{[2]}$ Ultraviolet light, ionizing radiation, heavy metals, air pollution, cigarette smoke, heat, chemotherapeutic drugs are considered exogenous factors. ${ }^{[2]}$ When damage to the genetic material cannot be repaired, recombination, mutation, tissue damage, aging, and cancer may occur as a result of DNA sequence changes, and single or multiple nucleotide changes that may result in chromosomal aberrations..$^{[2,3]}$

\section{GENOTOXIC AGENTS AND THEIR MECHANISMS OF ACTION}

It is estimated that a single cell may experience up to a million changes in a day as a result of these factors. ${ }^{[2]}$ Exposure of DNA to this extent of damage may prevent replication or transcription. Therefore, understanding of "genotoxic" and "mutagenic" substances carries importance.

These agents are divided into two groups: physical and chemical. Physical agents include heat, $\mathrm{pH}$, and rays (ionizing radiation, ultraviolet [UV], etc.). Chemical agents include base analogues, alkylating agents, and intercalating agents.

Physical factors have effect similar to heat and $\mathrm{pH}$, and show effect through denaturation. Rays are named according to energy and wavelength within the electromagnetic spectrum. X-rays, gamma rays, and cosmic rays have shorter wavelengths and therefore higher energy. These rays can penetrate deep into tissues and cause ionization in molecules they encounter. 
$\mathrm{X}$-rays take the electrons from the atoms of the molecules they encounter and cause the atoms and molecules to convert from their stable state to free radicals and reactive ions. Molecules that form as a result of these reactions can directly or indirectly affect DNA. By changing purines and pyrimidines, they cause point mutations. ${ }^{[4]}$ In addition, ionizing radiation breaks phosphodiester bonds and disrupts the integrity of chromosomes. ${ }^{[4,5]}$

Ultraviolet light induces formation of pyrimidine dimers, binding two adjacent pyrimidines (thymine) with a cyclobutane ring, forming thymine-thymine dimers. These dimers block replication and transcription. ${ }^{[6]}$

The chemical agents, base analogues, may also cause DNA damage. This damage may occur with all bases. Base analogues are structurally similar to purines or pyrimidines. Therefore, they replace normal bases during replication contributing to DNA structure and disrupting normal base pairing. This leads to transitional mutation and spontaneous tautomerization. ${ }^{[7]}$

Other DNA bases outside of thymine contain exocyclic amino groups. These groups can be separated with the effect of water and free radicals. As a result of this separation, cytosine converts to uracil, adenine to hypoxanthine, and guanine to xanthine. This deamination damage is caused by mismatches during replication, which leads to gene mutations. Cytosine converting to uracil is especially the most important biological deamination; since uracil is not a DNA base, it prevents RNA and DNA synthesis and causes cell death. In addition, nitrites also cause deamination of adenine converting it to hypoxanthine, interrupting the DNA replication process. Deamination of guanine converts it to xanthine (xanthine cannot pair with other bases) resulting in deletion and disruption of the DNA pairing process.

Alkalylating agents cause serious damage to DNA. This is because they add methyl and ethyl groups to various positions of bases. Nitrogen mustard is also known as war gas. Alkyl sulfate ester and sulfonic esters are commonly used industrial alkylating agents. Alkylating agents used in cancer treatment (cyclophosphamide, cisplatin, mitomycin) cross-link with DNA, preventing cancer growth and division. This is because all alkylating agents are electrophilic compounds. They transfer alkyl group to nucleophilic regions of DNA bases. Alkylation results in formation of crosslinks in DNA and proteins. Cross-links in DNA causes serious DNA damage and interruption of replication and transcription process, ultimately leading to cell death. ${ }^{[6]}$

When we look at other damage mechanisms of DNA, purine and pyrimidine bases can be destroyed with hydrolysis. Free radicals (fluoride, peroxide, metal ions) cause breakage in DNA. DNA analogues (5-bromouracil, 5-fluorouracil, 2-aminopurine) are analogous to DNA bases, replacing them and read as bases during DNA coupling. However, this transcription of mismatches causes mutations.

Peroxide and free radicals cause disconnections in the ring structures forming DNA bases. Hydroxyl and superoxide radicals are found in automobile gases and cigarette smoke. It reacts with guanine, converting it to 8-hydroxydeoxyguanosine. This change is considered a biomarker of oxidative damage to DNA. ${ }^{[6]}$

\section{DETECTION OF DNA DAMAGE}

It is known that hormone, enzyme, carbohydrate, and protein metabolism is affected by the cellular stress factors stated above, causing physiological and morphological changes. However, determining whether or not these stress factors have caused damage to DNA in regions encoding biochemical mechanisms, and if so, identifying the degree of damage is vital to the organism's health and future. ${ }^{[8]}$

Recent developments in molecular cancer genetics have shown that most cancers are associated with protooncogenes and mutations in tumor suppressors as a result of genotoxic agents. Genotoxicity tests are used to both identify these agents and their effects on the gene. These tests have been used since the 1970s and since then, many in vivo and in vitro genotoxicity tests have been developed. So far, a large number of techniques have been used to identify DNA damage, many of which require expensive and long study time and sometimes involve many laboratories or technical infrastructures (radioactive workplaces), making it difficult to achieve the expected success at the end of the study. ${ }^{[8,9]}$ 
Looking back at the history of these tests, they include: the Ames test, Thymidine Kinase assay, Micronucleus test, FADU (Fluorescence Analysis of DNA Unwinding), FISH (fluorescent in situ hybridization) for detection of chromosomal translocations, p53 mutation assay, detection of apoptosis, aneuploidy assay with anticentromere antibodies and COMET (SCGE: Single Cell Gel) Electrophoresis methods. ${ }^{[10]}$

The Ames test, or the Salmonella/microsome mutagenicity test, was developed in the 1970s by Professor Bruce Ames. It is an inexpensive, fast, and easy method to investigate the effects of potential mutagenic substances. It uses Salmonella thyphimurium lacking the ability to synthesize histidine through mutations in different regions of its histidine operon. It is based on mutant Salmonella strains, in the presence or absence of mammalian liver post mitochondrial supernatant (S9) containing cytochrome P-450 enzymes, that are subjected to a second mutation after possible mutagen addition and histidine expression and proliferation in a non-histidine setting. It is assumed that strains that reproduce in nonhistidine broths spontaneously mutate again after exposure to the agent and are therefore genotoxic. Mutagenicity of the given substance is determined by counting these colonies. ${ }^{[10-13]}$

Another mutagen analysis method, is the single cell gel electrophoresis method, also known as the Comet assay. In terms of its expanding field of application and safety, it allows measurement of the damage levels of genotoxic and cytotoxic effects caused by possible mutagenic agents on living organisms. ${ }^{[8]}$ DNA from living tissues is fixed in a thin agarose gel and run through electrophoresis. If DNA is damaged or cannot be repaired, or if there are breaks in single or double DNA chains, they will migrate at different rates in electrophoretic environment as the molecular weight and charge of the broken DNA molecules will change. DNA molecules such as ethidium bromide are stained with DNA-specific dyes and examined under a fluorescent microscope to determine the degree of damage. Since DNAs produce images of varying degrees from a circular form to a comet-like form, this method is named the Comet Assay. ${ }^{[8]}$
The most commonly used method in DNA damage detection is $\mu$-FADU (Fluorometric DNA Unwinding Analysis). Compared to the Comet method, both methods are based on the detection of alkaline degradation in DNA under appropriate denaturing conditions. Similar to the Comet method, the $\mu$-FADU method quantitatively evaluates changes in the amount of fluorescence. COMET uses fluorometry and $\mu$-FADU uses spectrofluorometry as methods of measurement. While COMET assesses tail length and momentum, $\mu$-FADU evaluates change in the intensity of fluorescence. ${ }^{[4]}$

\section{Declaration of conflicting interests}

The authors declared no conflicts of interest with respect to the authorship and/or publication of this article.

\section{Funding}

The authors received no financial support for the research and/or authorship of this article.

\section{REFERENCES}

1. Clancy S. DNA Damage \& Repair: Mechanisms for Maintaining DNA Integrity. Nature Education 2008; $1: 103$

2. Kurtoğlu EL, Tekedereli İ, DNA Onarım mekanizmaları. Balıkesir Sağlık Bilimleri Dergisi 2015;4:169-177

3. Kramer PJ. Genetic toxicology. J Pharm Pharmacol 1998;50:395-405.

4. Bedir A, Bilgici B, Yurdakul Z, Gürsel BŞ, Alvur M. DNA hasar1 analizinde $\mu$-FADU ve COMET yöntemlerinin karşılaştırılması. Türk Klinik Blyokimya Dergisi 2004;2:097-103.

5. Miyakoshi J, Yoshida M, Shibuya K, Hiraoka M. Exposure to strong magnetic fields at power frequency potentiates X-ray-induced DNA strand breaks. J Radiat Res 2000;41:293-302.

6. Jun S. DNA Chemical damage and its detected. International Journal of Chemistry 2010;2:261-5

7. Sun Julong, Yang Guanghui, He Guozhong. DFT study on tautomerism of gaseous cytosine. Chinese $\mathrm{J}$ Chem Phys 2005;18:325-30.

8. Dikilitaş M, Koçyiğit A, Canlılarda "tek hücre jel elektroforez" yöntemi ile DNA hasar analizi (teknik not): comet analiz yöntemi. HR.Ü.Z.F. Dergisi 2010;14:77-89.

9. Tice RR, Agurell E, Anderson D, Burlinson B, Hartmann A, Kobayashi $\mathrm{H}$, et al. Single cell gel/ comet assay: guidelines for in vitro and in vivo genetic toxicology testing. Environ Mol Mutagen 2000;35:206-21.

10. Şekeroğlu ZA, Vedat Şekeroğlu V. Genetik toksisite testleri. TÜBAV Bilim Dergisi 2011;4:221-9. 
11. Vural N. Toksikoloji. Ankara: Ankara Üniversitesi Eczacilık Fakültesi Yayınları; 2005. s. 115- 29.

12. Choy WN. Genetic toxicology and cancer risk assessment. New York: Marcel Dekker 2001. p. 29-187.
13. Tepekozcan A. İndium tin oksit ve bizmut (III) oksit nanomateryallerinin mutajenik özelliklerinin ames test ile araştırılması. (Yüksek Lisans Tezil, Afyon: Afyon Kocatepe Üniversitesi; 2013. 